\title{
O mundo greco-romano de Konstandínos Kavafis
}

\author{
The Greco-Roman World of Konstandínos Kavafis
}

\author{
Victor Ribeiro Villon ${ }^{1}$ \\ ${ }^{1}$ Doutor e Mestre em História pela Pontifícia Universidade Católica do Rio de Janeiro (PUC-Rio). E-mail: \\ victorvillon@gmail.com.
}

Recebido em 1ㅇ de outubro de 2019; Aceito em 21 de janeiro de 2020

\section{Resumo}

O presente artigo pretende refletir sobre a recepção da história antiga e bizantina na obra de Konstandínos Kaváfis (1863-1933), poeta grego, membro da comunidade helênica de Alexandria. Acreditamos que podemos denominar o material histórico com o qual Kaváfis trabalha como "greco-romano", no entanto, o termo assume contornos próprios quando analisado a partir da ótica do poeta alexandrino. Assim sendo, ao refletirmos sobre o "mundo greco-romano de Kaváfis", estamos igualmente a refletir sobre o referido período histórico em si mesmo e nas características que o constituem na tradição historiográfica.

Palavras-chave: Recepção; História Cultural; Literatura; Poesia.

\section{Abstract}

This article aims to reflect about the reception of Ancient and Byzantine history in the work of Konstandínos Kaváfis (1863-1933), Greek poet, member of the Hellenic community of Alexandria. We believe that we can call the historical material with which Kaváfis works as "Greco-Roman", however, the term takes on its own outlines when analyzed from the perspective of the Alexandrian poet. Therefore, when reflecting about the "Greco-Roman world of Kaváfis", we are also reflecting on that historical period itself and on the characteristics that constitute it in the historiographical tradition.

Keywords: Reception; Cultural History; Literature; Poetry.

\section{Entre Gregos Romanos e Bizantinos ou Considerações sobre o termo Greco-Romano}

$$
\text { Muito poderíamos escrever }{ }^{115} \text { sobre o termo greco-romano. Sob tal }
$$

\footnotetext{
115 O presente artigo compõe a dissertação de mestrado intitulada: "Konstandinos Kavafis e o Mundo Greco-Romano: Dálogos entre a História e a Poesia", defendida no Programa de Pós-Graduação em História Social da Cultura/Departamento de História da Pontifícia Universidade Católica do Rio de Janeiro, Rio de Janeiro, 2009.
} 
denominação uma verdadeira epopéia histórica pode placidamente repousar. O problema, porém, é sabermos as fronteiras dessa palavra. Por mundo greco-romano podemos remeter-nos a distintos períodos: aos primórdios da civilização grega, desde a chegada dos primeiros indo-europeus aos extremos da península balcânica - para alguns, na transição do Heládico Antigo II para o Heládico Antigo III, por volta de 22002100 a.C - até a queda do Império Romano do Ocidente, em 476. Esse imenso período, de mais de vinte cinco séculos, pode ser apreendido ora como os desenvolvimentos de uma mesma cultura - com os seus mais diversos matizes, através dos tempos - ora como sendo, especialmente, o resultado da confluência da cultura grega com a cultura romana, que se deu na conquista e expansão de Roma pela bacia do Mediterrâneo. Nesse último caso, o mundo greco-romano teria, em essência, desabrochado no período do Império Romano, quando as duas civilizações entram em contacto. Fascinados pelos cânones do pensamento e da arte gregos, o "agreste Lácio" teria, por fim, empreendido a obra de fusão e recriação dos dois mundos; mas não sem antes render-se à sedução dos que foram conquistados. Horácio, nas Epístolas, sintetizou com perfeição esse processo, na famosa frase que impregna, até os dias de hoje, nosso imaginário: Graecia Capta ferum victorem cepit et artes/ Intulit in agresti Latio, "A Grécia subjugada subjugou o seu feroz vencedor e introduziu as artes no agreste Lácio" (RÓNAI, 1980, p. 74).

Mas não poderíamos aí incluir Bizâncio? O Império Romano do Oriente, ainda que fosse de expressão helênica, não reivindicava para si as galas e as glórias do império que nascera nas colinas do Lácio? Constantinopla não recebera o epíteto de "Nova Roma", em conseqüência do translatio imperii do século IV? Não nos esqueçamos que, quando o rei dos hérulos, Odoacro, derrubou Rômulo Augústulo, do já mais que agonizante trono imperial, enviou as insígnias imperiais a Zenão de Constantinopla. 0 Império Romano do Oriente não perecerá nas convulsões que esfacelam definitivamente o ocidente latino. O envio das insígnias é um pequeno gesto, que materializa como aqueles homens percebiam a disposição da realidade da qual 
ISSN 1982-8713

participavam. Bizâncio haverá de atravessar a Idade Média como o helênico herdeiro de Roma. A reivindicação da herança imperial romana fazia-se patente nas próprias palavras de autodenominação. O termo "Bizâncio" é um emprego que se generalizou na Europa Ocidental, já tardiamente, no século XIV. A designação que os bizantinos davam, para o seu império, era $P \omega \mu \alpha v \iota \alpha$ (Romania) e, para eles mesmos, integrantes desse império, era 'P $\omega \mu \alpha$ ilo (Romaioi) (GUILLOU, 1974, 19-20). Mesmo que a tradição grecoromana se fizesse de forma muito diversa com novas influências e reinventada, isso em nada invalidaria a continuidade do seu pertencimento. Como bem sabemos, uma tradição viva sempre possui, ipso facto, a capacidade de plasmar-se em novas formas e Bizâncio não foi uma exceção; por esse ângulo, o mundo greco-romano poderia, talvez, abarcá-lo igualmente.

Por mais que os contornos do termo sejam fluidos, existe um núcleo nele de compreensão clara e, justamente por isso, acreditamos que seja válido o seu uso. Diríamos que greco-romano pode ser considerado como um verdadeiro topos de nossa cultura, que traz consigo, imediatamente, e, apesar de toda a sua complexidade, um sentido óbvio e objetivo, ou seja, a remissão à história antiga da Grécia e de Roma. Em uma ampliação do conceito, poderíamos adentrar até o Império Bizantino.

É mais do que conhecida a predileção de Kavafis por temas relacionados ao período helenístico. Mas nos atermos somente a esse viés, o helenístico, de seus poemas históricos seria fechar os olhos para vastos horizontes temporais que se fazem manifestos em sua obra. Nosso intuito não será definir o que deve ser entendido por mundo greco-romano, seguindo uma específica referência da historiografia, mas sim, partindo da própria obra de Kavafis, tentar deslindar o seu mundo greco-romano, que é construído com suas poesias.

Ele é greco-romano, pois Kavafis também concede seu sopro poético a personagens da história romana, como Antonio, César, Nero, Juliano o Apóstata. Os temas históricos, com os quais Kavafis trabalha, poderiam ser delimitados, grosso modo, 
como indo da temática dos poemas homéricos até a história bizantina. Esse é o particular mundo histórico no qual o poeta de Alexandria transita, mas não de forma linear e equitativa. Por exemplo, o século de Péricles, com a democracia ateniense, é praticamente ausente. Roma faz-se presente, como já sublinhamos, mas não com a mesma força e intensidade que a história do Mediterrâneo oriental de expressão grega. Roma inegavelmente está presente, mas, sobretudo, quando sua história cruza - o que seguramente não são poucas vezes - com a região historicamente helênica, a de predileção do poeta.

Entenda-se, desde já, que o sentido por nós adotado de "greco-romano" engloba não só a história da Grécia antiga e do Império Romano, mas, também, a do Império Bizantino. Pensamos que "greco-romano" é o termo que melhor se afigura para a descrição desse recorte cronológico, que se depreende dos poemas de Kavafis. Logo, a solução encontrada, para a definição da problemática fronteira desse conceito, basearse-á, sobretudo, na temporalidade da temática Kavafiana. Visto que o poeta bebe das águas dos caudalosos rios da história antiga, grega e romana - e dos seus desdobramentos bizantinos - serão os percursos desses mesmos rios que hão de definir e recortar o que seria esse mundo greco-romano. Deixemos nos levar mais pelas palavras do poeta de Alexandria do que por outras teóricas definições.

\section{No princípio era Homero...}

Os dois longos poemas homéricos, a llíada e a Odisseia - o primeiro com 15649 versos e o segundo com mais de 12000 - não somente principiam a literatura grega, mas também fundam o que conhecemos por literatura ocidental (SAÏD, TRÉDÉ, LE BOULLUEC, 2004, p.11). Mas a llíada e a Odisseia extrapolam o limite do literário, pois elas nos fazem enveredar pelos caminhos da relação dos antigos gregos com seus deuses. Para esses últimos, tudo o que era mais necessário e importante para a vida ali se encontrava. Depois de seguidos milênios de imposição e aparente naturalização das 
categorias do cristianismo, tendemos, por vício de pensamento, a relegar a narrativa homérica ao campo do mitológico. Entendamos aqui "mitológico" naquele sentido pedestre e cotidiano, que mais nos remete ao inverossímil fabuloso. Mas não podemos nos esquecer de que os mitos são profundas tentativas de apreensão e explicação do mundo e da existência humana. Para tanto, é suficiente observar que não há religião sem mito e, até aquelas, que se arvoram em mais racionalistas comungam dessas sagradas e insondáveis searas. Muitas vezes, perdemos a noção da centralidade das duas epopeias para os gregos pretéritos. A voz do aedo, que canta os fortes versos, não pode ser compreendida somente como a voz do poeta, tampouco como a do historiador. Digamos que ela possui traços de ambas, mas ela os ultrapassa. $O$ aedo possibilita uma rachadura do tempo presente, deixando que daí ascenda outra temporalidade. $\mathrm{O}$ tempo do mito é o verdadeiramente real - como nos ensinou Mircea Eliade - é ele que deverá fecundar o tempo comum, todas as atividades devem ser ungidas pelos exemplos dos deuses e heróis: "a função mais importante do mito é, pois, 'fixar as atividades humanas significativas: alimentação, sexualidade, trabalho, educação etc." (ELIADE, 1992, p.87) . Esse traço primordial, presente nas mais diversas culturas (ELIADE, 1992, pp.22-23), talvez nos leve a outras esferas da civilização grega, que podem, à primeira vista, parecer distantes. Estamos a nos referir ao aspecto que Jaeger chegou a chamar de Homero como Educador, título de um dos capítulos da sua Paideia. Ora, a centralidade de Homero, na formação do homem grego, não se liga à importância desse "tempo sagrado", do qual nos fala Eliade ? Pelo menos - no que tange à exemplaridade, da qual gozara a voz do aedo dos aedos, Homero - os alicerces da paideia grega jazem no canto das musas; na invocação do tempo da potência mítica; como diria ainda o pensador romeno: in illo tempore. É daí que se origina a penetrante influência do educador da Hélade. Influência essa que assim foi sintetizada por Jaeger:

A concepção do poeta como educador do seu povo - no sentido mais amplo e profundo da palavra - foi familiar aos gregos desde a sua origem e manteve sempre a sua importância. Homero foi apenas o exemplo mais notável dessa concepção geral e, por 
assim dizer, a sua manifestação clássica. Convém levarmos a sério, o mais possível, esta concepção, e não restringirmos a nossa compreensão da poesia grega com a substituição do juízo próprio dos gregos pelo dogma moderno de autonomia puramente estética da arte. (JAEGER, 1995, p.62)

As duas epopeias possuem uma longa história, tanto no que concerne à mimeses, mas também ao trabalho analítico e interpretativo que inúmeros pesquisadores e intérpretes Ihes vêm consagrando há séculos. Homero foi o educador da Hélade, como acabamos de ver, e a realidade de seus versos, em substância, não era posta em dúvida:

De fato, a antiguidade inteira - de Xenofontes (século VI a.C.) a Proculus (século $V$ d.C.), passando pelo cético Luciano (século II d.C) - acreditou na realidade de Homero e na historicidade dos acontecimentos que narra - a cólera de Aquiles durante a guerra de Tróia (que situava-se tradicionalmente em meados de 1200 aC.), ou a errância e o retorno de Ulisses a sua ilha de Ítaca. ${ }^{116}$ (SAï̀, TRÉDÉ, LE BOULLUEC, 2004, pp.11-12)

O que ficaria conhecido pelo nome de "Questão Homérica" terá seu primeiro arauto na pessoa do sacerdote e teórico do teatro francês: François Hédelin, Abade d'Aubignac, que se notabilizou, sobretudo, pela teorização das três regras do teatro clássico. Entretanto, em 1664, o Abade d'Aubignac escrevera as Conjectures académiques ou Dissertation sur l'lliade - manuscrito que só viria a público em 1774 nas quais defende que Homero não teria existido. A questão seria levada adiante pela publicação dos trabalhos do filósofo italiano Giambattista Vico; do inglês Robert Wood, em Essay on The Original Genius of Homer. Mas seria o filólogo germânico Friedrich August Wolf, que acreditava existir vários poetas sob o nome de Homero, que, ao

\footnotetext{
${ }^{116} \mathrm{~A}$ tradução é nossa, no original: "De fait, l'Antiquité tout entière - de Xénophon (Vle siècle av. J.-C.) à Proclus (Ve apr. J.-C.), en passant par le sceptique Lucien (Ile siècle apr. J.-C.), a cru à la réalité d'Homère et à l'historicité des événements qu'il raconte - la colère et les exploits d'Achille au cours de la guerre de Troie (qu'on situait traditionnellement autour de 1200 av. J.-C.), ou les errances et le retour d'Ulysse en son île d'Ithaque."
} 
escrever os Prolegomena ad Homerum, em 1795, divulgará nos meios intelectuais, a problemática em torno da autoria das duas epopeias. Como disse Jacqueline de Romilly: "desde então ela [a questão homérica] não cessou de gerar longos debates, que dividiram os filólogos e os dividem ainda hoje."(ROMILLY, 1995, p.20).

A teoria, que indicava a completa inconsistência histórica do relato homérico, teve um de seus expoentes na pessoa do banqueiro e historiador inglês, George Grote (1794-1871). Esse escrevera, ao longo de dez anos, uma monumental História da Grécia, em dez volumes. O grande historiador inglês contemporâneo, Moses Finley, assim citou as palavras do próprio Grote:

[Grote] [...] não hesitou em chamar ao episódio de Tróia uma "fábula interessante". Apesar do seu grande atractivo, escreveu: "é um erro separá-la do resto, como se repousasse numa base diferente mais merecedora de confiança." Há "dois caminhos, e apenas dois" abertos ao historiador: "passar totalmente por alto os mitos [...] ou descrevê-los como tal [...] e abster-se de os confundir com eventos vulgares confirmáveis". (FINLEY, 1990, p. 40)

Mas uma verdadeira reviravolta se daria com as descobertas de Heinrich Schliemann (1822-1890): essa interessante personagem, filho de um tirânico pastor luterano, nascido em Neubuckow, uma atrasada aldeia dos confins do Mecklenburg e que, segundo Duchêne: "nada predispunha [...] a se tornar o fundador da arqueologia pré-helênica." (DUCHÊNE, 1995, p.17). A ideia cada vez mais aceita, na Europa do século XIX, de que os poemas homéricos nada mais eram do que uma "fábula interessante", terá suas bases solapadas ou, pelo menos, muito enfraquecidas, através das descobertas de Schliemann.

Nos dias de hoje, com o resultado das pesquisas subseqüentes, sabemos que as afirmações de Schliemann devem ser relativizadas; mas também aquelas dos eruditos, como Grote, que viram a gênese da llíada e da Odisseia, unicamente, no estro ficcional de um ou de um conjunto de aedos. Em 1946, o helenista americano do Bryn Mawr 
College, Rhys Carpenter, concluía: "há algo de errado na Tróia, de Schliemann ou na de Homero". Tempos depois das escavações do arqueólogo alemão, constatou-se que os achados arqueológicos, tanto do sítio de Hissarlik quanto do de Micenas, eram anteriores à época provável da Guerra de Troia. Para Heródoto a Guerra de Tróia teria ocorrido por volta de 1250 a.C, porém os próprios antigos já divergiam nesse ponto: para Douris de Samos seria 1334 a.C, para Erarastostene em 1183 a.C., e para Éforo em 1135 (SAÏD, TRÉDÉ, LE BOULLUEC, 2004, pp.26). Foram encontradas nove Tróias: a mais opulenta, denominada Tróia VI, que durou por volta de seiscentos anos (1900-1300 a.C.), foi destruída não por uma invasão, mas sim por um terremoto. A cidade que aí se instalou, denominada Tróia VIla, após esse cataclismo, é que indicaria vestígios de uma destruição ocasionada por invasores estrangeiros. No entanto, Tróia VIla não corresponde ao fausto e à riqueza descritos por Homero para qualificar o reino do velho Príamo. Não se pode ler os poemas homéricos como escritos por um historiador, o que, aliás, seria totalmente anacrônico. Mas não podemos negar que ali se cruzam reverberações dos primórdios do passado do povo grego, com uma longa tradição oral e com o engenho e arte dos aedos, que a perpetuaram ao longo dos séculos, até que fosse fixada pela escrita. $\mathrm{O}$ cruzar desses elementos estão envoltos em brumas e jamais poderemos decifrá-los na sua integridade. Enfim, aqui bem podemos fazer nossas as palavras de Finley:

Os arqueólogos mostraram, de facto, que Tróia foi destruída nos fins do século treze, como alguns historiadores gregos posteriores tinham conjecturado, e que muitos dos locais relacionados com os heróis de Homero foram, com efeito, importantes centros micénicos. Por conseguinte, nos poemas resta um núcleo micénico genuíno e histórico, tal como fragmentos de passado sobrevivem noutros exemplos de poesia heróica: assim, na canção de Rolando, da França medieval, ou nas curtas baladas russas sobre o Príncipe Vladmiro de Kiev. (FINLEY, pp.18-19, 1988)

Todo esse debate e as minuciosas pesquisas, no campo da arqueologia, da filologia e da história, sobre a redação, os significados e a época dos poemas homéricos, 
ISSN 1982-8713

são testemunhos, mais do que eloquentes, do fascínio e da influência incontestes que a llíada e a Odisseia exerceram, e ainda exercem, não só na cultura ocidental, mas, também, em nosso imaginário. Kavafis, que era, por excelência, um herdeiro e recriador dessa tradição, não se furtou em revificá-la em sua obra. Mesmo que Kavafis não tenha dedicado uma grande quantidade de poemas aos temas e mitos homéricos, entre esses poucos encontramos vários repletos de grandeza literária, que se destacam pela amplitude de apreensão da condição humana. Em títulos como Os Cavalos de Aquiles

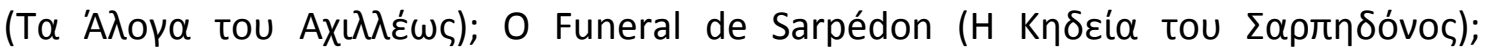

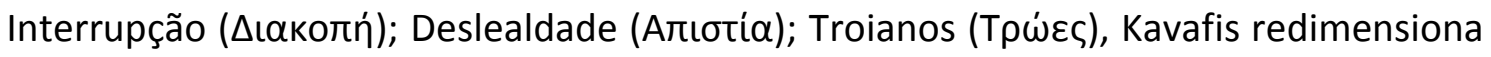
os episódios míticos, sejam diretamente retirados das duas epopéias ou, então, relacionados a essas.

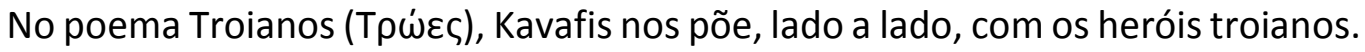
O poema principia com uma explícita comparação, visto que a ligação entre o leitor e os heróis faz-se através do advérbio "como", no original " $\sigma \alpha v "$ ". Mas o desencadear da sequência de versos parece transformar-se em um turbilhão, somos arrastados e, cada vez mais, aproximamo-nos das personagens míticas. Somos nós, os leitores, que fazemos as ações, porque os verbos são conjugados na primeira pessoa do plural. Kavafis supera a simples comparação, o que se faz notar pelo desaparecimento da palavra que a indicaria, isto é, o advérbio "como". O nome do maior dos Heróis troianos nem é mencionado no texto, pois os leitores é que ocupam o seu lugar: Aquiles está a nos fitar. Nos versos finais, não é, por exemplo, um paralelo que se traça, algo como: "Príamo e Hécuba por Heitor choram/ Nós como Heitor somos". Melhor do que dissecarmos um poema pujante de vida, será lê-lo em sua íntegra, ainda que traduzido:

São nossos esforços, os dos infortunados; são nossos esforços como os dos troianos. Conseguimos um pouco; um pouco levantamos nossas forças; e começamos a ter coragem e boas esperanças.

Mas sempre surge algo e nos detém. 
Aquiles no fosso, diante de nós, surge e com grandes gritos nos assusta.

São nossos esforços como os dos troianos.

Cremos que com decisão e coragem

mudaremos a hostilidade da sorte,

e ficamos do lado de fora para combater.

Mas quando a grande crise chega, nossa coragem e decisão desaparecem; nossa alma perturba-se, paralisa; e em torno das muralhas corremos, procurando salvar-nos pela fuga.

Contudo nossa queda é certa. No alto, sobre as muralhas, já começou o lamento.

Choram lembranças e sentimentos de nossos dias.

Amargamente Príamo e Hécuba por nós choram. (KAVAFIS, 2006, p. 73) 117

O poema parece basear-se, especialmente, no final da llíada. A imagem que logo nos vem à mente é o momento no qual Aquiles decide abandonar sua cólera e se põe a lutar novamente. Mas agora movido por uma segunda cólera, não mais aquela contra Agamêmnon, celebrada no primeiro e eterno verso de invocação: “Canta, ó deusa, a cólera de Aquiles, o Pelida". A segunda cólera de Aquiles, se assim podemos dizer, é a que se volta contra o assassino de Pátroclo: Heitor. Kavafis explora o pavor que dominou, até mesmo, o grandioso Heitor, ao defrontar-se com Aquiles, o maior dos guerreiros gregos. Assim nos diz Homero sobre o sentimento que perpassou Heitor naquele momento: "O medo dominou Heitor, assim que o viu. Não se atreveu/ a ficar onde estava, mas abandonou os portões e fugiu./ E o Pelida lançou-se atrás dele, confiante na rapidez dos pés." . O poeta de Alexandria universaliza os mesmos versos e faz com que vivenciemos a horrenda e sublime cena homérica: "Mas quando a grande

\footnotetext{
${ }^{117}$ A edição dos poemas de Kavafis utilizada é: KAVAFIS, Konstandinos: Poemas de K. Kavafis. Tradução
} de Ísis Borges da Fonseca. São Paulo: Odysseus, 2006. 
ISSN 1982-8713

crise chega,/ nossa coragem e decisão desaparecem;/ nossa alma perturba-se, paralisa;/ e em torno das muralhas corremos,/ procurando salvar-nos pela fuga."(HOMERO, CantoXII, 136-138) O que poderia parecer tão distante é reatualizado; Kavafis, tacitamente, implica qualquer um dos seus leitores na tradição homérica e, ao mesmo tempo, legitima-se no poema fundador de seu povo.

\section{O mundo helenístico}

Se há um período histórico - desse complexo cultural grego, romano e bizantino - onde a poesia de Kavafis desabrocha com maior prolificidade é, sem dúvida, nos tempos helenísticos. Não estamos a afirmar que os mais belos e grandes poemas kavafianos aí se encontrem, pois, caso o fizéssemos, incidiríamos em uma escolha, a partir de critérios meramente pessoais. Não podemos nos esquecer de que o mundo homérico, com seus heróis e mitos, pode não figurar em muitos poemas. No entanto, 0 encontramos entre as mais belas e interessantes páginas do poeta alexandrino; é

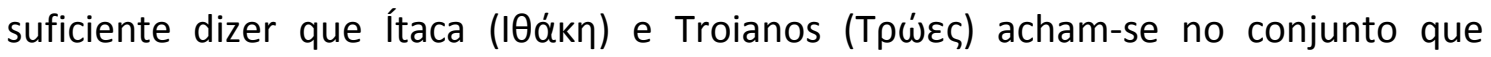
poderíamos chamar de "mítico/homérico". Seguramente, é aos críticos literários e, sobretudo, aos leitores de Kavafis que cabe tal julgamento que, querendo ou não, sempre será de extrema subjetividade. Havemos de nos limitar à constatação de que a história helenística ofereceu numerosos temas a Kavafis. Devemos nos perguntar: "o que é mundo helenístico" e, em seguida: "por que Kavafis tanto reviveu esse período em sua poesia?".

A tradição historiográfica não é unânime quanto ao início e ao término da época helenística. Na maior parte das vezes, estabelece-se, como marco cronológico para o período, a morte de Alexandre o Grande, em 323 a.C., e a célebre Batalha de Actium, em 31 a.C., que desfez os sonhos de Marco Antonio e Cleópatra de construírem um 
NEARCD: Revista Eletrônica de Antiguidade 2020, Volume XII, Número I - ISSN 19882-8713

Núcleo de Estudas da Antiguidade -NEA

Universidade do Estada do Rio de Janeiro

ISSN 1982-8713

império oriental ${ }^{118}$. Mas como assinala Saïd: há quem o faça começar com a ascensão de Alexandre ao trono de seu pai Filipe II da Macedônia, em 336 a.C.. Outra possibilidade seria considerar a vitória de Queronéia, quando o mesmo Filipe vence a coalizão de Atenas e Tebas, em 338 a.C.. Mas bem sabemos que tais datas nada mais são do que simples pontos de referência. Acima das pequenas divergências cronológicas, o que devemos reter são a singularidade e as amplas correntes que movimentaram o espírito do tempo, nesses, aproximadamente, trezentos anos - entre o projeto do macedônio, de uma monarquia universal, e a queda das monarquias helenísticas sob a Pax Romana - quando a língua e a cultura grega extrapolaram os seus tradicionais limites. As conquistas de Alexandre o Grande mudaram as dimensões do ser grego. Desde então, a dicotomia entre gregos e bárbaros não mais se havia de fazer com a antiga e forte nitidez de outrora. Segundo Chamoux, a palavra "helenístico" teria primeiramente sido empregada em referência ao idioma grego escrito pelos judeus helenizados, no qual figuravam palavras e expressões hebraicas. Para Hecateu de Abdera, a postura de Ptolomeu I Sôter em relação aos judeus teria feito de Alexandria uma terra de acolhimento. Em "outra [versão] de origem alexandrina e judaica, mais tardia, os primeiros imigrados teriam sido prisioneiros capturados pelo mesmo Ptolomeu durante uma campanha na Síria, e libertados por ele." (MOSSÉ, 2004, p.155). Na capital dos lágidas a cultura judaica floresceu. Uma das mais célebres realizações dessa comunidade foi a tradução da Bíblia para o grego, que ficaria conhecida pelo nome de Septuaginta. Era a esse tipo de texto que primeiro aplicou-se a denominação de "helenístico". Foi somente com o historiador germânico Johann Gustav Droysen, já no século XIX, que Hellenismus foi empregado para nomear a história da civilização de base helênica que se espalhara graças às conquistas de Alexandre o Grande. Talvez a escolha de Droysen já mostre em si o traço, eminentemente, de contato entre culturas que caracterizou

\footnotetext{
${ }^{118}$ Entre os autores que adotam essas duas datas como marcos para início e término da época helenística, Cf. PETIT, Paul e LARONDE, André: La Civilisation Hellénistique, p. 3. Também Cf. MOURRE, Michel: Dictionnaire Encyclopédique d'Histoire.
} 
esse período histórico.

Mas a cidade de Alexandria não foi somente um grande centro da comunidade judaica, ela foi o "modelo", se assim podemos dizer, do que entendemos pelo conceito de "helenístico". Como afirmou Mossé: "É incontestável que o cerne do que chamamos, desde Droysen, a civilização helenística consistia na cidade fundada por Alexandre durante sua breve permanência no Egito." (MOSSÉ, 2004, p.155) . O sentimento da importância da cidade de Alexandria no período helenístico faz-se patente no poema A

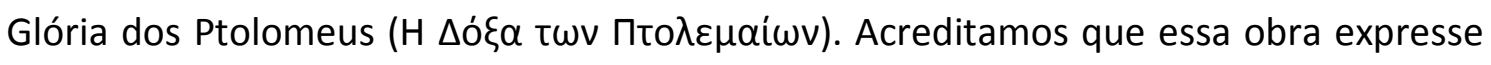
muito da relação de Kavafis com o mundo helenístico. Kavafis vai até o passado para encontrar o seu lugar, pois Alexandria, agora, é uma cidade árabe. Sem sombra de dúvida, trata-se de uma urbe cosmopolita, com florescentes comunidades de estrangeiros - a grega é a mais numerosa delas - porém Alexandria não mais é a polis grega dos tempos helenísticos. A Alexandria contemporânea a Kavafis é totalmente diversa: majoritariamente e em pleno território árabe. O poeta exalta a memória dessa Alexandria perdida: meio realidade, meio ficção, expoente do espírito grego que recebe a qualificação de "cume pan-helênico". O século V a.C., o de Péricles, pode ter sido glorioso, mas não divulgou a civilização grega aos quatro cantos e, talvez, por isso, ele pouco apareça na obra kavafiana. Kavafis considera-se filho de um pan-helenismo, que agora só existe no passado, que pode ser recriado em poemas como A Glória dos Ptolomeus (H $\Delta$ ó $\xi \alpha \tau \omega v \Pi \tau o \lambda \varepsilon \mu \alpha i \omega v)$ :

Sou o Lagida, rei. Perfeitamente conhecedor (com minha força e minha riqueza) do prazer. Macedônio ou bárbaro, não se encontra ninguém igual a mim, ou mesmo que de mim se aproxime. É ridículo o Selêucida com sua sensualidade vulgar.

Contudo, se vós procurais outras coisas, ei-las também aqui claras:

a cidade mestra, o cume pan-helênico, em cada discurso, em cada arte, a mais sábia. (KAVAFIS, 2006, p. 99) 
ISSN 1982-8713

\section{"Para as grandes honrarias de nossa raça": alguns aspectos da História de Bizâncio}

A forma como os homens percebem a sua história e como as imagens dessas percepções cristalizam-se no imaginário, seguramente, nos dizem muito sobre a visão que os povos têm de si mesmos. Essas acabam por fazer, com toda legitimidade, parte da história, pois fundam ideais e transformam o mundo que nos cerca. Poderíamos apropriar-nos da acuidade poética de Fernando Pessoa, para sintetizarmos esse aspecto: "Assim a lenda se escorre/ A entrar na realidade./E a fecundá-la decorre. Em baixo [sic], a vida, metade/ De nada, morre." (PESSOA, 1995, p.72) Os estertores do Império Bizantino ocupam um lugar fundador para a consciência dos neogregos: tanto do ponto de vista que mais se aproxima dos domínios do imaginário - enquadrando-se nesse contexto de percepções e cristalizações - quanto daquele que entendemos, mais propriamente, como o da história.

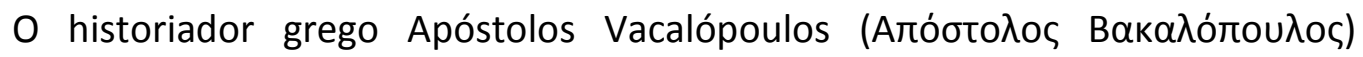
escolhe o ano de 1204 para dar início ao seu livro, História da Grécia Moderna, isto é, a data da invasão de Constantinopla pelos cruzados francos: “Então justamente, em 1204, chega o grande terremoto que desperta a consciência nacional adormecida dos habitantes: a abolição do Império Bizantino pelos francos [...]" (VACALÓPOULOS, 1995, p.35). Diríamos nós que a escolha de Vacalópoulos traduz, de algum modo, a força simbólica de Bizâncio, como tempo crucial, para os alvores do despertar da autoconsciência da Grécia moderna. Não temos pretensões em afirmar a validade dessas considerações, à luz do estado da historiografia atual, o que, aliás, escaparia das nossas possibilidades, visto que exigiria profundos conhecimentos sobre as pesquisas e debates historiográficos realizados nos últimos tempos na Grécia. Nosso simples objetivo é observar o lugar ocupado por Bizâncio no imaginário da Grécia moderna. E para Vacalópoulos é já nos derradeiros momentos do Império do Oriente, no contato com o elemento invasor estrangeiro, que professava o cristianismo de rito latino e era fiel ao papa, que começa a brotar, pelo menos, as fagulhas de pertencimento a uma determinada identidade. Façamos ouvidos às próprias palavras de Vacalópoulos: 
A tradição popular e a vida das províncias encontram a oportunidade de desenvolver suas forças latentes, de projetar suas tendências centrífugas e acentuar seu helenismo. Os cavaleiros francos, com seus numerosos pequenos estados devem enfrentar esses núcleos de resistência dos bizantinos, ou melhor, dos gregos. Porque, na realidade, a partir dessa época, desde 1204-1566, o mundo helênico resiste, incluindo as regiões dominadas pelos francos, seja ativa ou passivamente. E essa resistência que começa já desde os primeiros dias, e a qual enfatizei no primeiro tomo da minha História do Neo-helenismo (1a Ed. 1961), com o passar do tempo se torna mais eficiente e mais tenaz. Os improvisados soldados locais que, no princípio, fugiam e se dispersavam, aterrorizados frente aos orgulhosos cavaleiros de férreas armaduras, que chegavam a sentir vergonha por seus adversários, em pouco tempo, sob a inspirada liderança de militares capazes como os irmãos Constantino e Teodoro Láscaris de Nicéia, ou Miguel Comneno, Duque do Epiro, não só suportam senão que, transformados agora em combatentes aguerridos, devolvem os golpes com firmeza. (VACALÓPOULOS, 1995, p.36)

Para conseguirmos melhor compreender o que, segundo a argumentação de Vacalópoulos seria "o gênesis do neohelenismo" - quer dizer: o que "das ruínas e do caos que deixou o furacão da quarta cruzada [e fez] brota [r], cheio de vigor, o novo helenismo" (VACALÓPOULOS, 1995, p.36) - devemos abordar, embora de maneira sucinta, esse primeiro golpe, provindo do Ocidente, do qual os bizantinos foram alvo. 0 fim do reinado de Manuel Comneno é considerado o princípio dos tempos do declínio de Bizâncio (CHEYNET, 2006, p.97). Kavafis escreveu um poema sobre Manuel Comneno

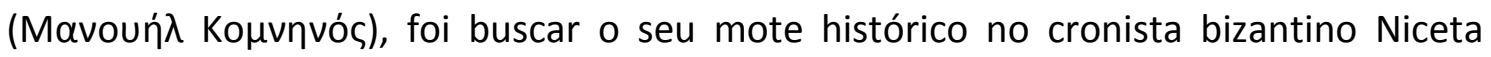
Acominatos (CASTILLO DIDIER, 2003, p.370). Assim sendo, pensamos que não haveria melhor forma do que iniciar a sucinta explicação pelo próprio texto kavafiano:

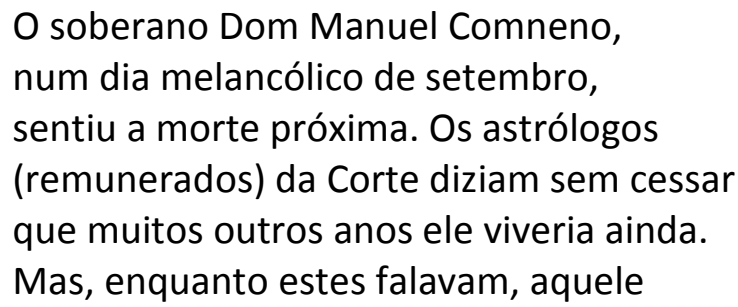


se lembra de velhos costumes piedosos, e ordena que das celas dos monges Ihe tragam hábitos eclesiásticos; veste-os e alegra-se por mostrar um aspecto venerável de sacerdote ou de monge.

felizes todos os que crêem, e que, como o soberano Dom Manuel, terminam Revestidos de sua fé, humildemente (KAVAFIS, 2006, p. 155).

O poeta alexandrino nos relata um soberano doente, já a sentir a proximidade do seu ocaso; os astrólogos tentam demovê-lo da ideia que a morte já estaria chegando; mas Comneno "se lembra dos velhos costumes piedosos/ e ordena que das celas dos monges the tragam hábitos eclesiásticos" . Após vesti-lo, o poeta faz com que o imperador sinta uma espécie de alívio, liberto que estava do peso das glórias terrenas: "Felizes todos que crêem,/ e que, como o soberano Dom Manuel, terminam/ revestidos de sua fé, humildemente." . Yourcenar, ao comentar Manuel Comneno (Mavouń入

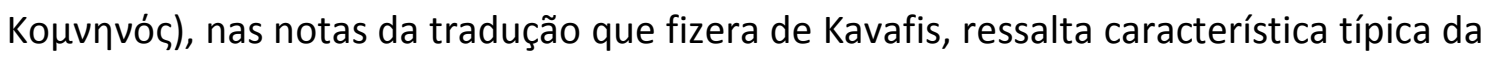
reelaboração do autor, que se dá aqui mais uma vez: “[...] o detalhe histórico, cuidadosamente segmentado, separado do contexto, adquire um significado quase oposto àquele que sugerem as fontes". O significado além de ser quase oposto às fontes, também se universaliza. A estrofe final da poesia sintetiza o que podemos aprender a partir do ato de Manuel Comneno diante da iminência da morte. Kavafis vê na particularidade, o fato da personagem histórica vestir-se com hábitos sacerdotais, o ensejo para a reflexão de questão que aflige todos os seres humanos: como havemos de nos preparar para defrontarmos o misterioso olhar da morte.

Mas há uma segunda perspectiva para lermos o poema, que se liga à relação de Kavafis com o passado de suas gentes, os gregos. Aventaríamos a Manuel Comneno

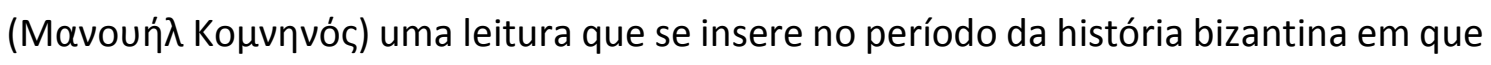
viveu essa personagem. Antes de retratar a personalidade do soberano, os versos pretendem retratar o declínio de Bizâncio, que se seguiria, desde então, 
vertiginosamente. Pouco antes de morrer,em 1176, o Imperador fora derrotado, em Miriocéfalo, pelos turcos seljúcidas. Segundo Runciman isso "[...] significava que os turcos se haviam instalado ali para sempre" (RUNCIMAN, 1977, p.43) . Era o prenúncio da queda, aliás, uma das questões humanas mais exploradas por nosso autor.

Não muitos anos depois da morte do imperador Manuel Comneno, que tivera lugar em 1180, ascenderia, ao trono de S. Pedro Lotário di Segni. Esse, sob o nome de Inocêncio III, trazia consigo ambicioso projeto para estender o poder papal acima de todos os outros poderes terrenos, porque "julgava-se, como papa, colocado em algum ponto entre Deus e a humanidade - menos que Deus, mas maior que os seres humanos." (MCBRIEN, 2000 ,p.98) No mesmo ano de sua ascensão, o papa convocará uma quarta cruzada. O movimento será encabeçado por Bonifácio Marquês de Monferrato, Balduíno Conde de Flandres, Geoffroi de Villehardouin, entre outros. Apesar dos milhares de homens, quando em 1202 estão prestes a partir em direção do Egito, constata-se que o número de cruzados é insuficiente e, sobretudo, faltam recursos para pagar os custos da viagem, devidos ao governo de Veneza. A solução encontrada é tomar a cidade de Zara, nas costas da Dalmácia, pomo da discórdia entre os venezianos e os húngaros. Zara, desde 1186, encontrava-se sob domínio do rei da Hungria. O ensejo para um acerto de contas punha-se diante dos Venezianos e o velho doge, Enrico Dandolo, não o recusou. Mas atacar Zara era atacar terras cristãs. Inocêncio III ameaçara com a excomunhão aqueles que fizessem guerra contra outros cristãos, irmãos na fé. Mas as engrenagens bélicas já estavam em marcha: em novembro de 1202 a cidade é saqueada pelos cruzados. Depois da tomada de Zara, sob o pretexto de restabelecer no trono bizantino o imperador deposto, Isaac II Angelus, "os cruzados atacaram Constantinopla e conseguiram transpor as formidáveis muralhas que permaneceram invioladas até esse dia de 12 de abril de 1204" (CHEYNET, 2006 ,p.98). Seria com a quarta cruzada - a dominação dos cruzados francos que se desviaram de seus primeiros fins e invadiram Constantinopla - que despertariam os primeiros indícios do renascimento da consciência dos gregos, segundo Vacalópoulos. Mas a 
quarta cruzada seria sobretudo um grave golpe para a autonomia de Bizâncio.

Talvez ao abordar a resignada postura do imperador Manuel Comneno Kavafis esteja, de certa forma, remetendo-se ao declínio de Bizâncio, que haveria de começar, aos estertores das glórias de seu povo. Depois de explanar sobre o Império do Oriente a poesia histórica de Kavafis queda-se. Quem sabe para o poeta de Alexandria o tempo presente aí teria começado, desprovido do encanto daquela força meio mítica, meio histórica que tanto o fascinava.

Kavafis não dedicou nenhuma de suas poesias ao período em que os gregos estiveram sob dominação turca, tampouco à guerra de independência da Grécia. Porém, ao período bizantino foram várias as obras consagradas. Aliás, lembremos que Bizâncio é o limite temporal de Kavafis, os temas de seus versos históricos não se estendem além daí. Uma hipótese - para que o poeta tenha ido até os tempos bizantinos e não, por exemplo, aos da revolução grega de 1821 - seria o seu conceito de "grecidade", que deveria extrapolar os limites estreitos de um patriotismo circunscrito ao Estado Grego. Seu amor ao passado, reforçado por suas origens constantinopolitanas, e a condição de grego da diáspora, talvez o fizessem identificar-se com a amplidão do helenismo e com as glórias da história do seu povo. O crítico literário grego Timos Malanos, que conhecera Kavafis pessoalmente, deixou um elucidativo depoimento sobre tal questão, que vem a endossar nossa hipótese:

Quando fazemos a pergunta, Kavafis responde, que ele não é ' $\pi \alpha \tau$ เ

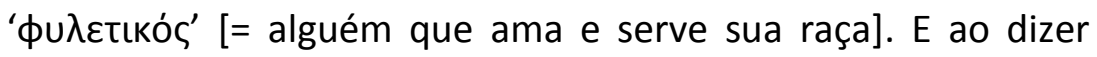

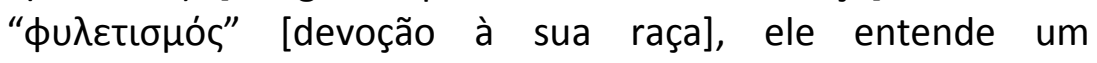
restabelecimento inteiro da raça grega. Que seja anexado à Grécia atual cada lugar tendo uma consciência grega, como por exemplo o Pontos e as costas da Ásia Menor, que sempre atraiu, metade poética, metade historicamente, sua imaginação. Em

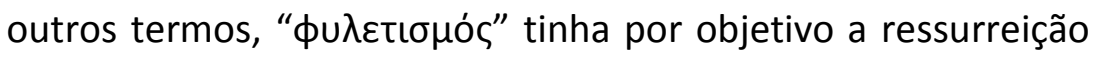
de um Bizâncio grego. Mas eram suas idéias até a catástrofe de 1922. Eu não sei quais foram suas ideas após essa data; mas eu estou certo que elas não devem ter mudado, ou então elas 
NEARCD: Revista Eletrônica de Antiguidade 2020, Volume XII, Número I - ISSN 1982-8713

Núcleo de Estudas da Antiguidade -NEA

Universidade do Estada do Rio de Janeiro

ISSN 1982-8713

mudaram muito pouco. ${ }^{119}$ (MALANOS apud HAAS, 1996, p.106)

O Estado Grego independente, fruto do romantismo do século XIX e da aspiração à autodeterminação dos povos, legitimou-se, sobretudo, na Grécia clássica do século $\mathrm{V}$ a.C.. Era especialmente o período clássico que fascinava as potências da Europa Ocidental. A imagem da opressão dos descendentes daquele povo, que dera à humanidade o "milagre grego", fazia com que muitos idealistas angariassem fundos e até mesmo lançassem-se na luta pela independência:

Na Europa ocidental despertou um grande entusiasmo por parte da opinião pública liberal quando receberam notícias da sublevação e, em questão de dias, voluntários filohelenos entre os que contava lord Byron - começaram a se alistar para lutar pela causa da liberdade grega. Alguns deles, educados com uma imagem idealizada da Grécia clássica descobriram que os gregos modernos tinham pouco em comum com as gloriosas figuras da Atenas de Péricles. ${ }^{120}$ (CLOGG, 1998 ,p.27)

No entanto, o passado bizantino, seguramente, tinha algo de mais palatável, para uma parte da sociedade grega mais afeita aos valores religiosos, do que o paganismo da época clássica. Em Kavafis o paganismo não seria um problema, mas isso não significaria uma rejeição aos valores cristãos, dos quais Bizâncio era, por excelência, símbolo. Na segunda metade do século XIX, havia na Grécia um debate entre os

\footnotetext{
${ }^{119}$ A tradução é nossa, no original : "Quand on lui pose la question, Cavafy répond qu'il n'est pas

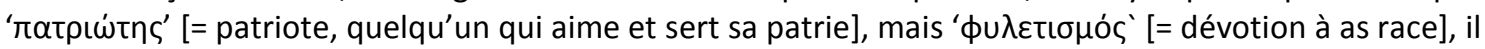
entend un rétablissement entier de la race grecque. Que soit annexé à la Grèce actuelle chaque lieu ayant une conscience grecque, comme par exemple le Pont et les côtes de l'Asie Mineur, qui attiraient toujours,

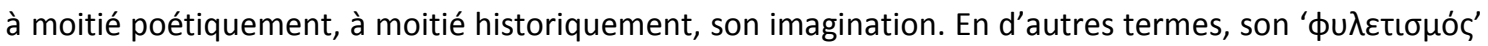
avait pour objectif La résurrection d'une Byzance grecque. Mais c'étaient ses idées jusqu'á la catastrophe de 1922. Je ne sais pas quelles étaient ses idées après cette date ; mais je suis certain qu'elles n'ont pas dû changer, ou bien qu'elles ont changé très peu. " Malanos, Timos: 'O Пoıntns K. П. Kaßáфnc. 'O

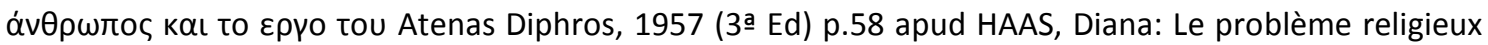
dans l'œuvre de Cavafy. p.106

${ }^{120}$ A tradução é nossa, no original: “En Europa occidental se despertó un gran entusiasmo por parte de la opinión publica liberal cuando se recibieron noticias de la sublevación y, en cuestión de días, voluntarios filohelenos - entre los que se contaba lord Byron - empezaron a alistar-se para luchar por la causa de la libertad griega. Algunos de ellos, educados en una imagen idealizada de la Grecia clásica se descubrieron que los griegos modernos tenían poco en común con las gloriosas figuras de la Atenas de Pericles."
} 
NEARCD: Revista Eletrônica de Antiguidade 2020, Volume XII, Número I - ISSN 19882-8713

Núcleo de Estudas da Antiguidade -NEA

Universidade do Estada do Rio de Janeiro

ISSN 1982-8713

detratores e os defensores de Bizâncio, segundo nos explica Diana Haas ${ }^{121}$. De um lado, haveria os que reivindicavam a herança das luzes e eram influenciados pela leitura de autores como Edward Gibbon e Ernest Renan. Esse grupo punha-se "[...] contra a escalada de uma onda religiosa onde o cristianismo foi identificado com a reabilitação de Bizâncio, e, por extensão, com a política da grande 'ideia' ." (HAAS, 1996, p.15). Já, no lado da defesa de Bizâncio, havia os intelectuais gregos, como Scarlatos Vyzantios

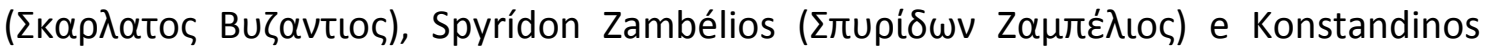

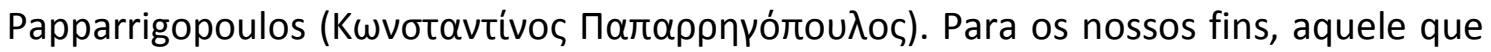
mais nos interessa é Paparrigopoulos. Esse nascera em Constantinopla, em 1815, foi professor da Universidade de Atenas, cidade onde veio morrer em 1891, e é considerado o historiador nacional da Grécia. Seu mais célebre trabalho foi uma imensa obra, intitulada História da Nação Helênica: dos tempos antigos até hoje (Iotopía tou

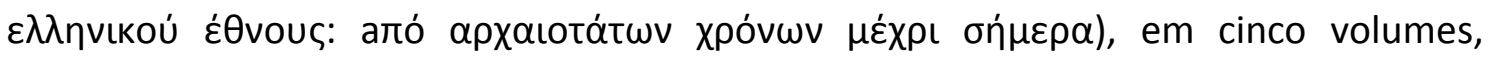
publicada entre os anos de 1860 e 1876 . Terrades o compara, aludindo ao historiador francês do período romântico, a "uma espécie de Michelet do helenismo"(TERRADES, 2005 ,p.28). Paparrigopoulos defendeu a continuidade do povo grego, desde os seus primórdios até o advento do Estado independente. Kavafis foi um grande admirador de Paparrigopoulos e comungou muito de suas teorias. Haas, que estudou as anotações que o poeta fizera sobre o clássico livro de Gibbon, Declínio e Queda do Império Romano, afirma: "[...] primeiramente ficamos impressionados pelo magistério que exerceu sobre Kavafis a obra do historiador romântico grego Konstandinos de Paparrigopoulos."(HAAS,1996,pp.6). Kavafis não só sofreu a influência Paparrigopoulos, mas o considerava uma autoridade na qual poderia confiar, pois continua Haas: "por várias vezes, no curso da leitura de Decline and Fall [Declínio e Queda do Império Romano], Kavafis recorreu à análise de Paparrigopoulos para verificar, ou, o mais frequente, para refutar o relato feito por Gibbon de certos acontecimentos da história

\footnotetext{
${ }^{121}$ Cf. HAAS, Diana: Le problème Religieux dans l'oeuvre de Cavafy: les années de formation (1882-1905).
} Paris: Presses de l'Université de Paris-Sorbonne, 1996. 
bizantina." (HAAS, 1996, pp.5-6) .

Mas, ainda assim, Kavafis parecia deter-se na história de Bizâncio, possivelmente, não pelas mesmas razões dos mais apegados aos ditames da Igreja Ortodoxa e dos homens de fé. O poeta de Alexandria possuía as suas próprias razões para ligar-se a Bizâncio. Acreditamos que se tratava muito mais de razões de ordem identitária do que religiosa. No belo poema Na Igreja ( $\Sigma \tau \eta v ~ Е к к \lambda \eta \sigma i \alpha$,$) Kavafis expressa$ uma concepção estética e histórica da fé:

\author{
Amo a igreja - seus hexaptérigas, \\ a prata de seus vasos sagrados, seus candelabros, \\ suas luzes, seus ícones, seu púlpito. \\ Quando entro na igreja dos gregos: \\ com os perfumes de seu incenso, \\ com as vozes e os coros litúrgicos, \\ as majestosas presenças dos sacerdotes, \\ e o ritmo solene de cada um de seus gestos- \\ esplêndidos no adorno de suas vestes sacerdotais- \\ meu espírito vai para as grandes honrarias de \\ [nossa raça, \\ para nossa gloriosa cultura bizantina (KAVAFIS, 2006, p. 117).
}

$\mathrm{Na}$ juventude nosso autor pode ter defendido o cristianismo ortodoxo e, talvez, continuou a fazer essa defesa pelo resto da vida. Mas, como se dá a entender, Na Igreja

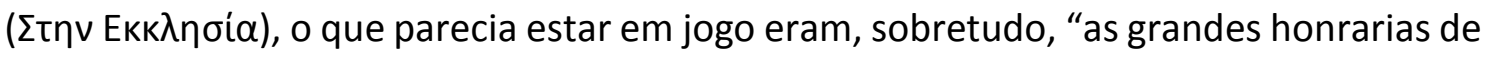
nossa raça [de kavafis]", bem mais do que algum testemunho de fé ou de rito, que o religasse à esfera da transcendência. Se acaso o poeta compõe a fileira dos defensores da Igreja Ortodoxa é especialmente porque, no final das contas, a Igreja se transmuta em um sinônimo do "glorioso bizantinismo".

Escutamos os saudosos ecos das glórias pretéritas de Bizâncio - que parecem emanar das profundezas do imaginário histórico - em De vidro colorido (Aлó vaגí $\chi \rho \omega \mu \alpha \tau$ ¿tó). Kavafis abre o poema confessando que determinado episódio da história 
bizantina muito o comove. O episódio em questão é a coroação do Imperador João VI Cantacuzeno, que ocorrera no palácio de Blaquerna em 1347. Cantacuzeno fora general e o principal colaborador do Imperador Andronico III; esse último tentava reerguer o desgastado Estado Bizantino, quando a morte Ihe sobreveio. Segundo Bréhier: “um só homem, João Cantacuzeno, era capaz de continuar essa obra, mas ele recusara de ser revestido da autoridade imperial, que teria sido necessária para o seu êxito." (BRÉHIER, 1992, p.355). Mas investir-se da dignidade imperial implicava uma ruptura com a legitimidade, pois Cantacuzeno não pertencia à dinastia dos Paleólogos. O herdeiro da coroa de Andronico III era seu filho, João V Paleólogo, quando da morte do pai contava apenas nove anos de idade. Em todo caso, a regência caberia a Cantacuzeno, apesar da pouca simpatia que a rainha viúva, Ana de Savoia, devotava ao que fora o homem de confiança de seu marido e imperador morto. As intrigas contra Cantacuzeno fizeram com que, finalmente, a rainha viúva o destituísse do cargo. Mas Cantacuzeno não aceitou a decisão e levantou armas contra seus adversários: durante vários anos, de 1341 a 1347, o Estado Bizantino foi devastado por uma guerra fratricida. O resultado foi a vitória das forças de Cantacuzeno - apoiado em grande parte pelos arcontes e religiosos - que se fez proclamar imperador, sob o nome de João VI:

[...] difícil era o restabelecimento da ordem e da prosperidade. Os cofres do Estado estavam vazios ao ponto que não se pôde mesmo celebrar dignamente as festas da coroação de João VI e de Irene, que aconteceram na igreja do palácio em 12 de maio [1347]. Uma tentativa do basileus para fazer com que os notáveis de Constantinopla contribuíssem com suas rendas para o restabelecimento das finanças públicas defrontou-se com uma incompreensão total. (BRÉHIER, 1992, p.358)

É a imagem dessa coroação empobrecida, metáfora do próprio Bizâncio, que chegara a fazer uso de pedaços de vidro colorido no lugar de pedras preciosas, que fascinou Kavafis. A solução encontrada pelos imperadores pode afigurar-se como uma atitude leviana: pedras ordinárias que se fazem passar por tesouros da coroa. Mas para Kavafis não há: "nada de humilhante ou de indigno [...], [n]esses pedacinhos de vidro 
ISSN 1982-8713

colorido. Parecem, ao contrário, um triste protesto contra a injusta desventura dos coroados". Poderíamos ler a poesia como uma revolta contra a iminente queda do povo grego; o poeta parece revoltar-se contra o imponderável: contra o curso da própria História. Mas como dizíamos, o que poderia ser visto como artificial e falso é transmutado por Kavafis: eis o símbolo de um digno, silencioso e altivo protesto que se volta contra o injusto destino de seu povo; contra as desventuras da existência. Leiamos o poema na íntegra:

Muito me comove um pormenor na coroação, em Blaquerna, de João Cantacuzeno e de Irene, filha de Andronico Asán. Como tinham somente poucas pedras preciosas (de nosso desafortunado estado era grande a pobreza) usaram artificiais. Uma quantidade de pedacinhos de vidro, vermelhos, verdes ou azuis. Nada de humilhante ou de indigno têm, em minha opinião, esses pedacinhos de vidro colorido. Parecem, ao contrário um triste protesto contra a injusta desventura dos coroados. São os símbolos do que convinham terem, do que seguramente era justo terem em sua coroação, um Dom João Cantacuzeno, uma Dona Irene, filha de Andronico Asán (KAVAFIS, 2006, p. 295).

\section{Referências Bibliográficas}

BRÉHIER, Louis. Vie et mort de Byzance. Paris : Éditions Albin Michel, 1992.

CASTILLO DIDIER, Miguel. Kavafis Íntegro. Santiago de Chile: Quid Ediciones, 2003.

CHEYNET, Jean-Claude. Byzance. Paris : PUF, 2006.

CLOGG, Richard. Historia de Grecia. Cambridge University Press (Sucursal Espanha). Madri, 1998. 
ISSN 1982-8713

FINLEY, Moses I. Aspectos da Antiguidade. Lisboa: Edições 70, 1990.

FINLEY, Moses I. Os Gregos Antigos. Lisboa. Edições 70, 1988.

KAVAFIS, Konstandinos. Poemas de K. Kavafis. Tradução de Ísis Borges da Fonseca. São Paulo: Odysseus, 2006.

HAAS, Diana: Le problème Religieux dans l'oeuvre de Cavafy: les années de formation (1882-1905). Paris: Presses de l'Université de Paris-Sorbonne, 1996.

McBRIEN, Richard P. Os Papas. Os Pontífices de São Pedro a João Paulo II. São Paulo: Edições Loyola, 2000.

RUNCIMAN, Steve. A Civilização Bizantina. Rio de Janeiro: Zahar Editores, 1977.

TERRADES, Marc. Le Drame de l'Hellénisme : Ion Dragoumis (1878-1920) et la question nationale en Grèce au début du XXe siècle. Paris: Harmattan, 2005.

VACALOPOULOS, Apótolos E. Historia de Grecia Moderna 1204-1985. Santiago: Universidad de Chile, Facultad de Filosofia y Humanidades, Centro de Estudios Fotios Malleros, 1995. 